\title{
Bir Reklam C̣ekiciliği Olarak Akıșkan Cinsellik: The Secret Life of Flowers Örneğinde Bir Çözümleme
}

\author{
Göksel GÖKER ${ }^{12}$ \\ Neslihan GÖKER ${ }^{3}$
}

\begin{abstract}
Öz
Cinsellik, en temel reklam çekiciliklerinden biridir. Günümüz reklamcılık anlayışı içerisinde, reklam iletisinin hedef kitleye en etkin şekilde ulaştırılması ve reklamın güçlü bir etki bırakması amacıyla, reklamlarda cinsel çekiciliklerin yoğun bir şekilde kullanıldığı görülmektedir. İstisnai durumlar olmakla birlikte, reklamlarda cinsel çekiciliğin çoğunlukla heteroseksüel anlam dünyası ve söylem düzeni içerisinde kullanıldığı ifade edilebilir. Cinselliğe ilişkin sosyo-kültürel, psikolojik ve ideolojik tartışmaların odağında normalliğe ilişkin tanımlamalar bulunmaktadır. Bu nedenle, cinsellik aynı zamanda bir kimlik problemi olarak değerlendirilir. Bir taraftan normal olan ya da normallik ölçütleri belirlenir, diğer taraftan da normal-dışılık, ötekilik veya marjinalliğin çerçevesi çizilir. Bu nedenle reklamlarda, genellikle normalliğin sınırları içerisinde işleyen bir cinsel çekicilik stratejisi devrededir. Bu çalışmada; normalliği aşan, katı heteroseksüel cinsel kimliği akışkan bir forma dönüştürerek fantazmatik bir atmosfer yaratan The Secret Life of Flowers reklam filminde kullanılan cinsel çekiciliğin analizi yapılmaktadır. Reklam çözümlenmesinde göstergebilimsel yöntem esas alınmış; reklam filminin genel betimlemesi, anlatı yapısı, kıyafetler ve anlamlandırmada kullanılan temel zıtlıklar analiz edilmiştir.
\end{abstract}

Anahtar Kelimeler: Akışkanlık, Cinsel Kimlik, Reklam, Göstergebilim, The Secret Life of Flowers.

Atıf (Cite as): Göker, G. \& Göker, N. (2020).

Bir Reklam Çekiciliği Olarak Akıșkan Cinsellik: The Secret Life of Flowers Örneğinde Bir Çözümleme. Akdeniz Üniversitesi Iletișim Fakültesi Dergisi, 34, 260-282. D01: 10.31123/akil.779895.

1 Doç. Dr., Fırat Üniversitesi, İletişim Fakültesi, Gazetecilik Bölümü, gokselgoker@gmail.com, ORCID: 00000002-5794-1122

2 Sorumlu Yazar (Corresponding Author)

3 Dr. Öğr. Üyesi, Fırat Üniversitesi İletişim Fakültesi, Radyo Televizyon ve Sinema Bölümü, neslihanyucesoy@ gmail.com, ORCID: 0000-0002-8294-8916. 


\title{
Fluid Sexuality as an Advertising Appeal: an Analysis in The Secret Life of Flowers Example
}

\begin{abstract}
Sexuality is one of the main advertising appeals. In today's advertising understanding, it is observed that sexual appeal is utilized in a dense way, for delivering the advertisement message to the target audience in the most effective way and the advertisement to leave a powerful effect. Besides exceptional cases, it can be expressed that, sexual appeal in advertisements is used, in majority, within heterosexual semantic world and discourse order. In the focus of social, cultural, psychological and ideological debates regarding sexuality, definitions related with sexuality exist. In one hand, one that is normal or normality measures are defined, on the other hand, abnormality, alterity or marginality are outlined. For this reason, in the advertisements, a sexual appeal strategy which functions generally inside the borders of normality is in operation. In this study, analysis for the sexual appeal, used in The Secret Life of Flowers advertisement film, which creates a phantasmatical atmosphere, transforming a solid heterosexual identity into a fluid form, surpassing normality, is made. In advertisement's assay, semiotic method is taken as basis; analyzing film's general description, narrative structure, costumes and main antagonisms used in interpretation.
\end{abstract}

Keywords: Fluidity, Sexual Identity, Advertisement, Semiotics, The Secret Life of Flowers.

\section{Giriș}

$\mathrm{R}$ eklamlar, günümüzde yalnızca bir ürünün tanıtımını ya da satışını amaçlamaz; bunun yanında reklamlarda üretilen ve markaya/ürüne iliştirilen anlam dünyası, reklamların tüketiciye bir yaşam tarzı, bir kimlik veya çeşitli aidiyet örüntüleri teklif ettiğini göstermektedir. Reklamların, tanıtımını yapacağı bir ürüne ihtiyaç duyması gibi ürünle birlikte tüketiciye cazip gelecek bir fikre, bir duyguya da ihtiyacı vardır. Bu nedenle reklamcılık faaliyetleri, bireyin salt maddi intiyaçlarını değil; sosyal statü, prestij, sınıfsal aidiyet ve kimliği ifade etme gibi birçok sosyal ve psikolojik intiyacı da karşılama çabası ve iddiası içerisinde olduğu görülür.

Reklamların tüketiciye bu içerimlerle birlikte seslenmesi; reklamcılık pratiklerini gerçekliğin dışına çıkaran, rasyonaliteden uzaklaştıran, daha çok ürünle muhayyel bir ilişkiyi tasarımlayan ve dayatan bir anlam dünyasını beraberinde getirmektedir. Reklamların, çoğu zaman bir anlatı formunda tüketicinin karşısına çıkmasının temel nedenlerinden biri de budur. Ürünü veya hizmeti aşan bir reklam, mutlaka ve mutlaka bir anlatıya başvurmak, hikâye ve olay örgüsü kurmak zorundadır. Bu tür reklamlarda çoğu zaman ürünün veya markanın geri planda kaldığı, hatta neredeyse görünmez olduğu, daha çok anlamların, imajların, toplumsal ilişkilerin inşa edildiği ya da tersine yıkıldığı bir durum söz konusudur.

Bir anlatı olarak reklamlar, edebiyat ve sinemada görülen fantastik türe sıklıkla yer 
vermektedir. Fantastiğin başka dünyalara ait yapısı ve gerçeklikle kurduğu ilişki, izleyiciyi çoğu zaman düşsel bir deneyime sevk etmektedir ve bu durum, tam anlamıyla reklamcılık pratiklerinin rasyonalite ile kurduğu çelişkili ilişkiyi tamamlaması bakımından oldukça önemlidir.

Reklamcılığın bir diğer başvurduğu anlatı ögelerinden biri de cinselliktir. Cinselliğin reklamlarda kimi zaman doğrudan, çoğu zaman da çağrışımsal düzlemde kullanılması, kuşkusuz "cinsellik her zaman satar" prensibinin bir sonucudur. Bir çekicilik türü olarak cinsel çekicilik, en başta izleyicinin dikkatini reklam iletisine çekmeyi, nihayetinde de markayı/ürünü bir arzu nesnesine dönüştürmeyi ve ürüne sahip olmakla cinsel cazibenin arttırılacağına ilişkin bir algının tüketiciye aşılanmasını amaçlamaktadır. Diğer taraftan reklamların cinsel çekiciliği kullanırken, çoğunlukla egemen eğilimleri yeniden ürettiği, heteroseksüel kimlikleri vurguladığı ve kadının cinsel obje olarak sunumuyla eril bakışı yeniden inşa ettiği görülmektedir.

Bu çalışma kapsamında analize konu edilen The Secret Life of Flowers reklam filminin cinsel çekiciliğe başvurduğu, ancak özellikle çağrışımsal düzlemde, sınırları aşan, akışkan ve müphem bir cinsellik söylemine sahip olduğu görülmektedir. Diğer taraftan The Secret Life of Flowers reklam filminin fantastik ögelerle zenginleştirildiği, izleyiciye düşsel bir evren çerçevesinde seslendiği ifade edilebilir. Bu açıdan The Secret Life of Flowers, yaygın reklamcılık anlayışından farkılış̧maktadır.

Reklam filminin çözümlenmesinde göstergebilimsel çözümleme yöntemi esas alınmıştır. Reklamın genel betimlemesi yapılmış; kişi, zaman, uzam ve söylemden oluşan anlatı yapısı, kıyafetler ile temel zıtlıklar analiz edilmiştir. The Secret Life of Flowers reklam filminin "normalliği" sorguladığı ve doğaya/cennete dönüş mitini yeniden ürettiği tespit edilmiştir.

Çalışma kapsamında, reklam filminin analizine teorik zemin teşkil etmesi bakımından kimlik, cinsellik, reklam ve arzu kavramları hakkında bilgi verilecektir.

\section{Kimlik ve Akıșkan Cinsel Kimlikler}

Kimlik, günümüzde sıklıkla kullanılan, sosyal ve psikolojik süreçleri açıklamakta başvurulan temel kavramlardan biridir. Kavramın bu denli yaygın ve popüler bir şekilde kullanılmasına rağmen, tanımlanması, sınırlarının çizilmesi konusunda sosyal bilimlerde bir belirsizliğin olduğu görülmektedir. Kimlik kavramına ilişkin belirsizliğin kökeninde öncelikle kavramın temel vurgusu önemli rol üstlenmektedir. Çünkü kimlik kavramı bir taraftan aynılığa, özdeşliğe vurgu yaparken, diğer taraftan farklılığa ve çeşitliliğe gönderme yapmaktadır. Günümüzde kavramın bu denli yaygın kullanılmasının temel nedenlerinden biri de son dönemde ortaya çıkan farklılık/çeşitlilik ve bu eksende ortaya çıkan tanıma/tanınma politikalarıdır.

Marshall, kimliğin, geniş kapsamda ve esnek biçimde, insanın kendi benlik duygusuna, kendisi hakkındaki duyguları ve fikirlerine atıf yapılarak kullanıldığını (1999, s. 407) belirtmektedir. Kavramın etimolojik kökenine bakıldığında ise aynılık ile kimlik kavramı arasında sıkı bir ilişki olduğu görülür. Gleason'un belirttiği gibi; kimlik, Latince idem (aynı) 
kökünden gelir ve İngilizcede 16. yüzyıldan itibaren kullanılmaya başlanmıştır. Popüler bir sosyal bilim terimi olarak kullanıma girmesi, ancak 1950'lerde gerçekleşmiştir (2014, s. 22-23). Aynılık vurgusunun yanında, Plummer'e göre kimlik, özdeşlik ve devamlılık anlamına gelmektedir. Terimin uzun felsefi geçmişi boyunca, değişim içinde kalıcılık, çeşitlilik içinde birlik temaları irdelenmiştir (2008, s. 418). Bu nedenle kimlik, çok sayıda insanı aynılaştıran, aynı varoluşsal düzleme yerleştiren ve bireyleri belirli bir olgu söz konusu olduğunda, özdeşlik ilişkisi içerisinde kategorize eden bir kavramdır. Örneğin milli kimlik, kültürel kimlik, dini kimlik, sınıf kimliği gibi çok sayıda kolektif kimliğin, bireyleri aynı kalıplar ve benzerlikler çerçevesinde değerlendirdiği, özdeşliği kurduğu görülmektedir. Bu anlamda kimlik, bir aidiyet problemine dönüşür. Kimlik, bireyin ait olduğu veya aidiyet bağıyla bağlandığı toplumsal ilişkiler ağına gönderme yapmaktadır. Aidiyet değişmedikçe, kimliğin de değişmeyeceği, dolayısıyla kimliğin durağan, sabit ve katı olduğu varsayılır.

Kimliği kişisel ve toplumsal kimlik olarak kategorize eden Parekh'e göre kişisel kimlik, bir bireyin mevcut dünyaya olan yaklaşımını ve bu dünyada bulunduğu konumu belirleyen inanış ve bağlılıklarını ifade etmektedir. Toplumsal kimlik ise bireyin kendini tanımlamasına ve kendisini bunun ayrılmaz bir parçası olarak görmesine vesile olan ilişkilere tekabül eder. Bir bireyin farklı kimlikleri tartması ve belli kısmına öncelik vermesi, kendi benlik anlayışı ile toplumsal ve siyasi ortamı arasındaki diyalektiğin sonucudur (2014, s. 53). İster kişisel kimlik, isterse toplumsal kimlik olsun, bireyin kendisini tanımlama biçimleri, birçok sosyal ve psikolojik faktörün devrede olduğu, dinamik ve değişken bir sürecin sonucunda ortaya çıkar. Dolayısıyla kimlik, sabit ve değişmez olarak değil, bireyin hem kişisel özellikleri ve tercihlerinin hem de girdiği toplumsal ilişkilerin değişmesi, farklılaşması sonucunda, kendisini uyarlayabilen ve kılık değiştirebilen bir olgu olarak değerlendirilmektedir.

Kimliğin bir diğer önemli çerçevesi; toplumsal, kültürel ya da siyasal zıtlıklar ve çelişsiler üzerine çizilmektedir. Rutherford, bu konuda egemen/baskın kimlik tasavvurları ile azınlıkta kalan ya da normalliğin dışına itilen kimlikler, bir başka ifadeyle "ötekilik" arasında, hiyerarşik bir ilişki olduğunu ifade eder. Rutherford'a göre (1998, s. 8) ötekilik, siyah-beyaz, eril-dişil, heteroseksüel-homoseksüel gibi kutuplaşmış kavramlar çerçevesinde kurulur. Bu zıtlık içeren terimlerin biri daima baskın, diğeri ise zayıftır ve kimlikler bu yönde biçimlenmiştir. Kimliğin kurucu ve biçimlendirici bir ögesi olarak hiyerarşik yapılanmalar ve tanımlamalar, bireyin kimlik edinme ve inşa süreçlerinde doğrudan doğruya etkilidir. Mollaer'in belirttiği gibi (2019, s. 31) "kimlik, varoluşumuza içkin; özdeşlik ile farkııık, aidiyet ile özerklik, güvenlik ile özgürlük, tikellik ile evrensellik gibi gerilimleri çevreleyen geniş bir politik spektrumda yer almaktadır." Böylelikle kimliğin bir mücadele alanına dönüştüğü, çoğu zaman siyasal, kültürel veya ideolojik bir toplumsal çerçeveye sahip olduğu ifade edilmelidir. Baskın olan, normalliğin sınırlarını belirlerken, bu sınırların dışında kalan her çeşit (öteki) kimliğin, toplumsal/ kültürel iktidarın tanımlama alanının dışına çıkmaya, görünürlük kazanmaya ve tanınma mücadelesi vermeye yöneldiği görülmektedir.

"Kimlik, ancak bunalımda olduğu zaman, sabit, tutarlı ve dengeli olduğu varsayılan bir şeyin yerini kuşku ve belirsizlik süreci aldığı zaman, sorun haline gelmektedir” (Mercer, 1998, s. 49). Dolayısıyla bilinenin, normal kabul edilenin dışına çıkmak, belirsizliği 
beslemek kimliği çoğu zaman bir problem alanına taşımaktadır.

Bu mücadele alanında birçok kimlik türü ortaya çıkmakla birlikte, bu mücadeleye konu olan en bilinen "öteki" kimlikler; etnik kimlik, kültürel kimlik, dini kimlik ve cinsel kimlik alanında ortaya çıkmaktadır. Cinsel kimlik söz konusu olduğunda, tıpkı kimlik kavramında olduğu gibi, belirsizlik ve çeşitlilik ön plana çıkmaktadır. Bu anlamda cinsel kimlik, cinsiyet kimliği ve toplumsal cinsiyet gibi cinselliği ve cinsiyet farklılıklarını vurgulayan ve içeren geniş bir kavramsal yelpaze bulunmaktadır.

Öncelikle cinsiyet ile toplumsal cinsiyet kavramı arasındaki farkı ele almak faydalı olabilir. İngilizcede bu iki kavramı belirten ve birbirinden ayıran sırasıyla "sex" ve "gender" kavramları bulunmaktadır. Dökmen'in belirttiği gibi; cinsiyet (sex) terimi, kadın ya da erkek olmanın biyolojik yönünü ifade eder ve biyolojik bir yapıya karşılık gelir. Toplumsal cinsiyet (gender) terimi ise kadın ya da erkek olmaya toplumun ve kültürün yüklediği anlamları ve beklentileri ifade eder (2012, s. 20). Bu noktada cinsiyet ve cinsellik kavramları düzleminde bir kimlik karmaşasının olduğu da ifade edilmelidir. Cinsel kimlik, bireyin hem biyolojik olarak hem de cinsel yönelimleriyle belirlenen (Budak, 2005, s. 168) bir kimlik türü olarak kabul edilmektedir. Cinsiyet kimliği ise kişinin kendisini belli bir cinsiyette hissetmesi, bir erkek ya da kadın olma duygusu (Dökmen, 2012, s. 27; Budak, 2005, s. 173) olarak tarif edilir. Cinsel yönelim olarak ifade edilen olgu ise cinsellik ile kimlik arasında kurulan ilişkiyi giderek çeşitlendirmektedir. Bu konuda baskın bir cinsel yönelim olarak heteroseksüelliğin yanında ve ötekiliğinde; homoseksüellik, biseksüellik, transseksüellik gibi cinsel yönelimler sonucunda çok sayıda cinsel kimlik ortaya çıkmaktadır. Dolayısıyla bir tarafta biyolojik belirlenimin, diğer tarafta ise kişisel eğilimler ve toplumsal/kültürel çevrenin, hem bu kimliklerin ortaya çıkması ve benimsenmesinde hem de algılanması ve toplumsal olarak konumlandırılmasında etkili olduğu görülür.

Sosyal bilimler içerisinde kimliğe ilişkin ortaya çıkan tartışmaların ve araştırmaların bir ucunda sosyolojik, diğer ucunda ise psikodinamik gelenek bulunmaktadır. Sosyolojinin kimliği özellikle toplumsal/kültürel belirlenimler çerçevesinde ele aldığı görülür. Cinsel kimlik söz konusu olduğunda, biyolojik belirlenim de dikkate alınır. Ancak psikodinamik gelenekte, psikanaliz kuramının temel aksiyomlarından biri olarak, anatominin cinsel konumu belirlemediği (Evans, 2019, s. 72) fikri kabul edilir. Evans'ın açıkladığı gibi, "öznenin erkek ya da kadının işlevini tamamıyla simgeleştirmesine izin verecek bir cinsel fark göstereni yoktur, dolayısıyla tam olarak "normal", bitmiş bir cinsel konuma erişmek mümkün değildir" (2019, s. 72).

Cinsel kimliklerin değerlendirilmesinde, hegemonik tekilleştirmeye karşı çeşitliliği ve farklılığı vurgulayan Queer teorinin önemli bir payı vardır. Queer kavramı; acayip, tuhaf, normal olmayan, şüpheli ve eksantrik gibi anlamları barındırırken, Queer teoride özneler geçici, hareket halinde, akışkan, değişken, her an yeniden tanımlanabilen-kurulabilen niteliklere sahiptir (Çabuklu, 2006, s. 65-70). Queer teorinin önemli teorisyenlerinden Butler, toplumsal cinsiyetin, verili bir cinsiyetin üzerine kültürün anlam işlemesi olarak anlaşılmaması gerektiğini ifade ederken, biyolojik cinsiyet ile toplumsal cinsiyet arasındaki verili olma ile inşa edilmiş olma ikilemini reddetmektedir. Butler'a göre toplumsal cinsiyet, aynı zamanda cinsiyetleri de tesis eden üretim mekanizmasının ta 
kendisidir (2012, s. 52). Butler ayrıca kimliğin değişmez, birleşik ve kendi içinde tutarlı bir yapı arz ettiği konusunu sorunsallaştırır ve biyolojik cinsiyet ile toplumsal cinsiyeti kuran toplumsal yasaların aynı zamanda süreksizlik ve tutarsızlık görünümlerini yasakladığını ve yeniden ürettiğini vurgular (2012, s. 66). Toplumsal yasalar özneyi değişmez, sabit ve süreklilik arz eden bir görünümün içerisine yerleştirerek, bunun dışında kalanların ötekileşmesine ve normalliğin dışına iterek marjinalleşmesine neden olmaktadır.

Özellikle cinsel kimlikler konusunda, günümüzde akışkan, sürekli yenilenen ve farklı deneyim alanlarına giren bir kimlik edinme/deneyimleme alanının açıldığı vurgulanmaktadır. Çabuklu'nun ifadeleriyle; "90'ı yıllardan itibaren çoklu, akışkan, hareket halinde iktidar yapılarının öne çıktığı” (2006, s. 74) görülür. Zizek’in tespit ettiği gibi: "günümüzdeki hegemonik öznellik biçimi, öznenin ahlaki özgürlüğünü garanti eden paternal Ödipal Yasaya itaat eden otonom özne değildir artık; kendini sürekli olarak yeniden keşfedip, yeniden kuran, farklı kimliklerden oluşan kombinasyonları keyifle deneyimleyen akışkan öznedir" (2018, s. 39). Yenilenme, yenilikleri deneme, farklı kimliklerin içerisine girme; kimlik ile deneyim arasındaki ilişkiyi gündeme getirir. Kimlik, akışkan bir deneyim alanında edinilen ve bırakılabilen, katı olmaktan öte oldukça esnek, değişime açık bir olguya dönüşmektedir.

Kimlik inşasının durdurulamaz bir deney şeklini aldığını (2017b, s. 103) belirten Bauman'a göre çağımızın parolası esnekliktir: "Tüm formlar yumuşak, tüm koşullar geçici, tüm şekiller biçimlenmeye uygun olmalıdır. Saplantılı ve bağımlı bir şekilde yeniden şekillenmek hem görev hem de zorunluluktur" (2018a, s. 124). Cinsel kimlikler, böylelikle bir deneyim sahası içerisinde, geniş bir anlam dünyasını sahiplenerek, akışkan bir niteliğe bürünerek çeşitlenmektedir. Bu durum edebiyatta ve sinemada çeşitli temsillere konu olmaktadır. Diğer taraftan reklamlarda da akışkan cinsellik hem bir anlatı unsuru ve çekicilik türü hem de tüketiciyi cezbetme aracı olarak kullanılmaktadır. Reklamlarda ortaya çıkan bu eğilim, reklamlar ile arzu arasındaki bitmeyen ilişkinin ve iş birliğinin sonucudur.

\section{Reklamlarda Arzu, Fantezi ve Cinsel Çekicilikler}

Günümüz reklamcılığının ana eksenlerinden biri, ürünü tanıtmanın yanında ve ötesinde tüketicilere bir yaşam tarzı sunmaktır. Reklamların ürüne iliştirdiği yaşam tarzı algısı ile kimlikler arasında doğrudan bir ilişki bulunmaktadır. Reklamlar bu yönüyle ürüne talep yaratmanın dışında, bireye ürünle birlikte erişebileceği bir kimlik vaat etmektedir. $\mathrm{Bu}$ kimliğin en temel bileşenlerinden biri de aidiyettir. Reklamlarda sunulan ürünlerin satın alınmasıyla birlikte, bireyin kendisini ait hissedebileceği bir toplumsal ilişki ağına gireceği reklamlar tarafından önceden kurgulanmaktadır. Reklamlarda üretilen; "zengin görünmek", "statü sahibi olmak", "belirli bir toplumsal sınıfa dahil olmak", "daha eril”, "daha dişil” gibi anlamlar, ürüne eklemlenen göstergelerle bireye aktarılmaktadır. $\mathrm{Bu}$ durum, reklamların bir anlam dünyası ürettiğini ve bunu bireye pazarladığını göstermektedir.

$\mathrm{Bu}$ nedenle, Lefebvre'ye göre en ustalıklı reklam formülleri, bir dünya görüşü 
içerir (2007, s. 121). "Reklamlar önceleri ürünün kullanım değerine ve fonksiyonel özelliklerine değinirken zamanla kişilerin yaşam tarzlarına, beğenilerine, sosyal değerlerine, bilinçdışı arzularına seslenmeye başlamıştır" (Güler, 2019, s. 16). Özellikle Post-Fordist dönemin bir uzantısı olarak reklamların bir çeşit tüketici sosyalizasyonu sağladığı, bilişsel ve duygusal açıdan tüketicileri etkileyen reklamların, bireylerin tüketim kültürüne eklemlenmesine neden olduğu görülmektedir.

Bir diğer önemli tespit ise Williamson tarafından yapılmıştır. Williamson'a göre reklamlar (2001, s. 13) içinde bireylerin ve o malların yer değiştirilebilir olduğu bir yapıyı vermektedir. Dolayısıyla reklamlar, bireylere yine kendilerini pazarlamaktadır. Çünkü reklamlar, ürünleri pazarlamaya çalışırken bireylerin duygularını, değerlerini, yönelimlerini ve arzularını yeniden üretmekte ve biteviye bir akışla bireye tekrar göndermektedir. "Reklamın açıkça yaptığı şey, bu nedenle, arzu nesnesini göstermektir, bize sunmaktır" (Williamson, 2001, s. 61). Bu noktada arzu, reklamcılık için önemli bir kavrama dönüşmektedir. Arzu, yapısı itibariyle doyurulması mümkün olmayan, paradoksal bir şekilde tatmin edildiğinde değil, tatmini ertelendiğinde işlevsel olan bir güdüdür. İhtiyaç ile arzu arasındaki farka değinen Evans'ın ifadesiyle; "karşılanabilen, dolayısıyla da başka bir intiyaç ortaya çıkana kadar özneyi güdülemeyi kesen intiyacın aksine, arzu asla doyurulamaz; kendi baskısı altında sürekli ve bitimsizdir. Arzunun gerçekleşmesi "doyurulmasına" değil arzunun bu şekilde yeniden üretilmesine bağlıdır" (2019, s. 41).

Lacan'a göre, insanın arzusu Ötekinin arzusudur (2014, s. 249). Lacan'ın arzuya ilişkin bu iddiasının farklı şekillerde yorumlandığını belirten Evans (2019, s. 41-42) bu iddiaya ilişkin 5 farklı yaygın yorumun bulunduğunu söyler. Bu yorumlardan birine göre; arzu daima başka bir şeye yönelik arzudur, zira birinin zaten sahip olduğu bir şeyi arzulaması mümkün değildir. Diğer taraftan Lacan'ın bahsettiği arzu bilinçdışıdır (Clero, 2011, s. 27) ve bilinçdışı arzu bütünüyle cinsel bir arzudur (Evans, 2019, s. 40). Bu nedenle arzu ile eksiklik fikri arasında sıkı bir ilişki vardır, ayrıca uyarılan bu arzu çoğu zaman cinsel eksikliği telafi etmeye dönüktür. Woodward, Baudrillard'ın tüketim toplumunda tüketim pratiğinin doğası üzerine yazılarının merkezinde "eksiklik" fikri olduğunu söyler. "Tüketim ve tüketimci kapitalizm, kapitalizmin her daim körüklediği ama asla tatmin edemediği bir psikolojik eksiklik üzerine bina edilmiştir" (2016, s. 197). Tüketim kültürü ve özellikle de reklamcılık pratikleri, eksikliğin inşa edilmesi ile gösterilmesi ve bu eksiklikler üzerinden arzunun harekete geçirilmesini amaçlamaktadır.

Reklamlarda sunulan arzunun doyurulması düşüncesi bir yanılsamadır ve reklamlar arzunun doyurulması ile değil, arzunun uyandırılması ve uyarılması ile ilgilidir. Bauman'ın dikkat çektiği gibi “bugünkü biçimiyle tüketim düzeni, Harvie Ferguson'un işaret ettiği gibi, "arzunun regülasyonu üzerine değil, ümit dolu fantezilerin serbest bırakılması üzerine kuruludur" (Bauman, 2017a, s. 120). Arzunun açığa çıkarılması ve uyarılması, diğer taraftan bu arzulara ilişkin reklamlarda düşsel ve muhayyel bir alanın açılması reklamların temel işlevlerinden birine dönüşmektedir. Bauman, tüketimciliğin tarihinin ve başarısının, fantezilerin serbestçe gezinmesini sınırlayan katı engellerin bir bir yıkılıp kenara atılmasının öyküsü olduğunu (2018b, s. 256) belirtirken fantezinin serbestçe dolaşıma sokulması ile tüketim kültürü arasındaki ilişkiyi vurgulamaktadır. Reklamlarda fantastik ve düşsel bir atmosferin yaratılması, çoğu zaman bunun cinsel 
arzuların uyandırılması amacıyla organize edilmesi ve markaya libidinal bir enerji yüklenmesi, Baudrillard'ın "reklam sözde olayın tam saltanatıdır" (2004, s. 160) önermesi ile örtüşmektedir. Sözde olay, düşsel olana ve fantazmatik alana göndermede bulunur. Bu noktada, reklamlarda bireylerin keyif alanlarına bir müdahalenin söz konusu olduğu görülür.

McGowan (2018, s. 309) fanteziyi, öznelerin ve toplumların keyiflerini organize etme biçimi olarak tanımlamaktadır. Bu nedenle reklam, fantazmaları kullanarak hedef kitleyi etkilemeye çalışmaktadır. Burada kişisel eğilimler, kişilerin gerçekleştiremedikleri düşler ya da gerçekleştirmek için eksiklikleri aktarılmaktadır (Küçükerdoğan, 2009, s. 109). Reklamlar ürün etrafında bir mitoloji inşa ederek ve düşsel sahneler yaratarak arzuları güdülemekte, organize etmekte ve yönlendirmektedir (Güler, 2019, s. 19).

Reklamın temelde gerçeğe değil, düşlere dayandığını söyleyen Berger'e göre reklamcılık bir çekicilik üretme sürecidir (2010, s. 131). Reklamlarda yaygın olarak kullanılan çekicilik türleri ise başta cinsel çekicilik olmak üzere, korku ve mizah çekiciliğidir. Bütün bu çekicilik türlerinin en temel amacı dikkat çekmek, ürünü cazip hale getirmek ve tüketicinin ürünle kurduğu ilişkiyi düzenlemektir. Günümüz reklamcılık anlayışı içerisinde, özellikle de arzu ve fantezileri yönlendirmek ve tüketimciliği pekiştirmek amacıyla, çoğu zaman örtük ve çağrışımsal olarak cinsel çekiciliklerin yoğun bir şekilde kullanıldığı görülür. Cinsel çekiciliklerin yoğun kullanımının arka planında; cinsellik, arzu ve fantezi arasındaki tamamlayıcı ilişki bulunmaktadır. Elden ve Bakır'ın açıklamasıyla, "cinsellik çağrıştıran reklamlar bireylere erotik fanteziler sağlama konusunda işlev görebilir. Bireyler bu reklamlarla kişisel olarak kabul edilebilir bir sapkınlık düzeyinde güvenli yoldan cinsel fanteziler yaratabilecek reklam karakterlerini görebilir" (2010, s. 161). Dolayısıyla reklamlar, ürünle ilişkilendirilebilecek ve bireyin düşsel alanına etki edebilecek bir fantezi geliştirme, inşa etme ve paylaşma mekanizması işlevini yerine getirir. Diğer taraftan Reichert'in belirttiği gibi reklamcılar, "cinselliği, bir markayı satın alma ve kullanmanın doğal sonucu olarak vaat ederler" (2004, s. 42). Böylelikle marka, cinselliği çağrıştıran ve hatta bireye cinsel deneyimi getiren/kazandıran bir öge olarak sunulur.

Edebiyatta ve sinemada yoğun olarak başvurulan bir anlatım tarzı olarak fantastik anlatı reklamlarda da sık sık kullanılır; "çünkü bu format ile izleyici reklam süresince başka bir ortama, yaşam tarzına götürülür. Bu anlatım formatının kullanıldığı reklamlarda yaratıcı öyküler, hayal gücü güçlü atmosferler yaratılır" (Elden, Ulukök ve Yeygel, 2014, s. 386). Cinsellik, fantastiğin önemli anlatı unsurlarından birini oluşturmaktadır. Todorov fantastik anlatının izleklerini anlatırken "sen" izleğinden bahseder. Bu izleğin temel ögesi cinsel istektir. Todorov'un belirttiği gibi kadına duyulan yoğun ama normal aşkın ötesinde, fantastik edebiyat, cinsel isteğin birçok dönüşümünü kapsar. Bunlar arasında ensest, eşcinsellik ve üçlü aşk gibi yaygın biçimler bulunmaktadır (2012, s. 129). Diğer bir ifadeyle fantastik edebiyat, aşırılıkları, aşırılıkların farklı biçimlerini anlatmaya önem verir (Todorov, 2012, s. 136). Dolayısıyla fantastik anlatı yalnızca egemen istek ve arzuların temsilinde ve uyarılmasında değil; sapkın, normal dışı, marjinal, öteki, yasak ve akışkan cinselliği ele almasıyla farklılaşmaktadır.

$\mathrm{Bu}$ çalışma kapsamında analizi yapılan The Secret Life of Flowers reklam filminin 
hem fantastik anlatım formatına sahip olduğu hem de Todorov'un vurguladığı şekliyle, normalliğin sınırlarını zorlayan ve aşan bir cinsel çekicilik stratejisine başvurduğu görülmektedir.

\section{Yöntem}

Reklam çözümlemesinde kullanılan yöntemlerin başında göstergebilimsel çözümleme gelmektedir. Reklamların giderek bir anlatıya dönüşmesi, görsel ve dilsel göstergelerle bireylere seslenmesi ve Barthes'ın terminolojisiyle, reklamların sahip olduğu temel mitsel işlevler; reklam çözümlemelerinde göstergebilimsel yaklaşımın benimsenmesine neden olmaktadır.

Göstergebilimin temel ilgi alanının merkezinde gösterge yer alır. Göstergelerin ve onların çalışma biçimlerinin araştırılmasına göstergebilim adı verilir (Fiske, 2003, s. 62). Diğer taraftan göstergebilimi yalnızca göstergelerle ilgilenen bir bilim dalı olarak nitelendirmek eksik bir yaklaşıma neden olacaktır. Bu nedenle Rifat'ın ifade ettiği şekliyle, göstergebilim burada doğrudan göstergeyle değil de anlamla, anlamlamayla, anlamın üretilmesiyle ilgilenen bir etkinlik olarak düşünülmektedir (Rifat, 2007, s. 29). Diğer bir ifadeyle göstergebilim, anlam üretiminin süreçlerini inceleyen bilimsel tasarı (Rifat, 2013, s. 100) olarak tanımlanabilir. Bu bakımdan göstergebilim, bir anlatı içerisinde sunulan anlamın, üretim süreçlerini ortaya koymak ve açıklamak üzere geliştirilmiş bir bilimsel yaklaşımdır.

Göstergeleri anlamlandırırken "çağrışımlar" önemlidir. Bireyler çağrışımlar aracılığıyla belli kavramlara belli imgeler yüklemektedir (Küçükerdoğan, 2009, s. 156). Reklam anlatılarında oluşturulan düşsel atmosferler, gerçeklikten koptuğu oranda çağrışımsal bir düzleme doğru kaymaktadır. Dolayısıyla reklam iletilerinin sunduğu anlamların çoğunlukla çağrışımsal, diğer bir ifadeyle yananlamsal bir boyuta sahip olduğu görülmektedir. Bu bakımdan göstergebilimin önemli temsilcilerinden Barthes'ın (2003 ve 2009) düzanlam ve yananlam sistematiğinin göstergebilimsel çözümlemelerde önemli bir yeri vardır. Düzanlam, bir dilsel birimin belirttiği anlamın öznel olmayan, değişmez öğesi (Rifat, 2013, s. 72) olarak tanımlanmaktadır. Yananlam ise bir dilsel birimin, öznel öğelerden oluşan ya da bağlamlara göre değişen anlamıdır (Rifat, 2013, s. 233). Bu açıdan reklamlarda hem düzanlamların hem de yananlamların kullanıldığı ifade edilebilir. Ancak 20. yüzyıl insanlarının bir yananlamlar uygarlığı içinde yaşadığını belirten Barthes'ın dikkat çektiği gibi (2009, s. 191-192) reklamların yananlamlı dili, ikili bildirisiyle alıcıların insanlık yaşamı içine düşü sokar. Bu düş bir taraftan yabancılaşmayı bir diğer taraftan da gerçeği içinde barındırır.

Yananlamlar ile düşsel atmosfer arasındaki ilişki, yananlamların alıcıda farklı düzlemlerde anlaşılabileceğini, düşsel deneyimin öznel bir süreç olarak tecrübe edilebileceğini ima etmektedir. Dolayısıyla göstergebilimsel çözümleme, özellikle de yananlamsal boyut söz konusu olduğunda, öznel değerlendirmelere imkân tanıyan, farklı okuma biçimlerini destekleyen bir analizdir.

Anlamların üretim süreçleri ile ilgilenen göstergebilimin temel kabullerinden biri 
anlamların zıtlıklar ve çelişkiler dolayımında inşa edildiğidir. "Göstergebilim, bir dizge oluşturan birimlerin aralarında, bir bağıntının, bir kurallı dayanışmanın bulunduğuna inanır; anlamın benzer ögelerden değil, karşıt ögeler arasındaki ilişkilerden doğduğu varsayımından hareket eder" (Rifat, 2009, s. 22). Hiçbir gösterge tek başına bir anlam taşımaz, bir göstergenin belirli bir anlamla kavranması, bu göstergenin diğer göstergelerle kurduğu ilişkiyi açığa çıkarmakla mümkündür.

Bu çalışma kapsamında The Secret Life of Flowers reklam filmi göstergebilimsel yaklaşım çerçevesinde çözümlenmiştir. Bu kapsamda sırasıyla; reklam filminin genel betimlemesi ve anlatısı yapısını oluşturan kişi, zaman, mekân ve söylem öğelerinin analizi yapılmış, reklam filminde kullanılan kıyafet ve desenlerin anlamları çözümlenmiş, reklamın sunduğu temel karşıtlıklar ele alınmıştır.

\section{The Secret Life Of Flowers Reklam Filminin Çözümlenmesi}

The Secret Life of Flowers ${ }^{4}$ (Çiçeklerin Gizli Hayatı) reklam filmi, H\&M'nin ERDEM koleksiyonunun tanıtımı için 2017 yılında gösterime girmiştir. Yönetmenliğini Moulin Rouge (2001), Australia (2008) ve The Great Gatsby (2013) gibi sinema filmleriyle tanınan Baz Luhrmann'ın yaptığı The Secret Life of Flowers reklam filminde; Hero Fiennes-Tiffin, Tom Rhys Harries ve Ruby Dagnall gibi oyuncular yer almıştır. Reklam filminde oyuncuların giydiği kıyafetler, H\&M'nin ERDEM koleksiyonuna aittir. Çoğunlukla renkli ve çiçek desenli kıyafetler içeren koleksiyon ile reklam filminde yaratılan atmosfer birbirini tamamlamaktadır.

Yönetmen Luhrmann, 4 dakikalık reklam filmi ile ilgili şu açıklamalarda bulunmuştur: "Filmin uzun metraj bir film gibi olmasını istedim. Kendi sırlarıyla dolu bir kır evinde geçen son derece modern bir aşk hikâyesi ve çağımızın bir metaforu gibi. Dünya zorlu bir yer olmaya devam ediyor, ancak burada, sonsuz bir ilkbahar içerisinde değerli şeyler büyümeyi sürdürüyor" (https://bit.ly/3iZ2fkX). Luhrmann'ın; "sırlarla dolu kır evi", "son derece modern bir aşk hikayesi" ve "çağımızın metaforu" gibi ifadelerinin reklam filmiyle ilgili önemli ipuçları sunduğu görülmektedir.

Diğer taraftan reklam filminin tanıtımını ve değerlendirmesini yapan birçok internet sitesinde (https://bit.ly/303kCwm ve https://bit.ly/3et1xbY örnek olarak verilebilir), The Secret Life of Flowers, "bir aşk üçgeni” öyküsü olarak tarif edilmektedir.

\subsection{Genel Betimleme}

The Secret Life of Flowers reklam filminin açılış sekansında, iki genç erkek Adam ve Tom (Hero Fiennes-Tiffin ve Tom Rhys Harries) 5 üstü açık, spor bir otomobille seyahat ederken görülür. İki genç, otomobilleriyle ağaçlar ve yapraklarla kaplı bir tünelden

4 Reklam filmini izlemek için: https://bit.ly/38U8NMS

5 Reklam filminde, ana karakter Adam (Hero Fiennes-Tiffin) ile ev sahibi Leydi Demare (Dame Harriet Walter) dışında diğer karakterlerin isimleri geçmemektedir. Bu nedenle reklam filminin diğer iki önemli karakteri, kendilerini canlandıran oyuncuların isimleriyle, Tom ve Ruby olarak anılacaktır. 
geçerek Redhamm Bahçesi olarak ifade edilen, bahçesi ağaçlarla kaplı büyük bir eve giriş yaparlar. Girişte Leydi Demare (Dame Harriet Walter) tarafından karşılanan gençler, belirsizlik ve kaygı içerisinde, rengarenk çiçeklerle kaplı bir holden geçerek eve doğru ilerler. Adam, eve geldikleri ilk günün gecesinde, kendisinin ifadesiyle; "genç, ünlü ve güzel insanların arasındayken, Leydi Demare'in bahçesinin yeni çiçeğinin" kendisi olup olmayacağını düşünür.

Adam, o gece Ruby Dagnall'ın canlandırdığı genç kadınla karşılaşır. Reklam filminde bu karşılaşmanın hemen sonrasında, kadının, Adam'ı eve getiren Tom'un kız kardeşi olduğu anlaşılır. Adam ile Ruby bir aşk yaşamaya başlarlar. Bu aşktan rahatsızlık duyan Tom'un hoşnutsuzluğunun nedeni ilk bakışta tam olarak anlaşılmamaktadır. Daha sonra Adam, Tom ve Ruby, ağaçlar ve çiçeklerle kaplı bir bahçede birlikte görünürler.

\subsection{Anlatı Yapısı}

İçerisinde bir öykü barındıran her bir anlatının, öyküyü sürükleyen çeşitli kesitlerden oluştuğu bilinmektedir. Anlatının yapısını belirleyen bu kesitler sayesinde, karakterlerin yaşadığını deneyimler, dönüşümler ve diğer karakterlerle girdiği etkileşim pratikleri açıklığa kavuşmaktadır. Böylelikle göstergebilimsel yaklaşımın temel ilgi alanı olan anlam üretim süreçleri okunabilmekte ve açıklığa kavuşturulmaktadır. Diğer taraftan, öykünün sahip olduğu kesitlerin dışında, anlatı yapısını şekillendiren diğer bazı öğeler bulunmaktadır. Bu öğeler; kişiler, mekân, zaman ve söylemdir. Anlatı yapı çözümlemesi bu öğeleri de içerisinde barındıran bir çözümleme sürecidir. Anlatı yapısı çözümlenirken, kesitler bu öğelerle birlikte analiz edilmiştir.

The Secret Life of Flowers reklam filminin sunduğu öykü, birbiriyle ilişkili üç kesitten oluşmaktadır. Bu kesitler kısaca başlangıç, dönüşüm ve kabullenim olarak nitelendirilebilir. Başlangıç kesiti her şeyden önce, yani değişim/dönüşümün ortaya çıkmasından önceki, normal ve sıradan durumu gösterir. Dolayısıyla bir anlatı içerisinde dönüşümün niteliğini ve anlamını kavrayabilmek, başlangıç aşamasını dikkate almayı gerekli kılmaktadır. Başlangıç kesitinde Adam ile Tom, bir otomobilin içerisinde hareket halinde görülür. Bu kesitte aynı zamanda reklam filminin ana karakterleri hakkında çeşitli izlenimler de verilmektedir. Tom, direksiyon başında, Adam'ı yönlendiren ve belirsizliklerin içerisine sürükleyen bir özne olarak konumlandırılmaktadır. Adam ile Tom arasında ilk kesitte ortaya çıkan diyaloglar, bu belirsizliği ve Tom'un dönüştürücü potansiyelini ortaya koymaktadır:

Adam: "Ailemin nerede olduğuma dair bir fikri yok. Kiminle birlikte olduğuma da."

Tom: "Senin de yok."

Bu diyalog, Tom'un belirsizliğini ve tekinsizliğini vurgulamasının dışında, Adam'ın "aile" kavramına gönderme yapmasıyla da önem taşımaktadır. Adam'ın bu ifadelerinde aile, bir tür kaygı merkezi ve normalliği koruyan otorite çağrışımlarıyla verilmektedir. Adam'daki ailesinin izni ve haberi olmadan hareket etmenin kaygısı bu diyalogla birlikte ortaya çıkar. Diğer taraftan Tom'un Adam'a verdiği cevap ise Adam'ın bile henüz bir şeyleri tam olarak bilmediği izlenimini oluşturmaktadır. 
İlk sahnede Tom'a ve Adam'a ilişkin oluşturulan izlenimlerin oldukça önemli olduğu ve reklamın ilerleyen sahnelerinde anlam kazandığı görülmektedir. Adam ilk sahnede "normal" bir erkek olarak konumlandırılmaktadır. Kısa saçları, kıyafetleri, ailesine bağlılığı ile Adam nezdinde, reklamda egemen normalliğin çerçevesi çizilmektedir. Diğer taraftan Tom ise Adam'dan farklıdır. Sıra dışı özelliklere sahip olduğuna ilişkin izlenimler ilk sahneden itibaren oluşturulmaktadır. Tom'un çiçekli fuları ve ayakkabıları ile saç şekli, Adam'ın aksine olağan dışı ve "normalliği" aşan özellikler sergilemektedir. Bu anlamda reklam filminin ilk sahnesinden itibaren "normallik" ile "normal dışılık" arasındaki sınırların Tom ve Adam karşıtığında çizildiği ifade edilmelidir.

Reklam filmi boyunca "normallik" ve "normal dışıık" zıtlığı çeşitli diyaloglarla ve görsel göstergelerle çizilir. Normallik ve normal dışılık birbirinin zıddı ve birbirini içermeyen olgular olarak sunulurken, normallik ve normal dışılığı birbirinden ayıran bir sınır çizgisi reklam filminde kullanılmaktadır. Eşik metaforu olarak kabul edilebilecek bu sınır, fantastik anlatının da temel dinamiklerinden birini oluşturmaktadır. Fantastik anlatıda kullanılan "bu eşik genellikle bilinen gerçeklikten, bilinmeyen gerçekliğe geçişte kullanılan bir kapı, bir tünel veya sihirli bir çemberdir" (Göker ve Göker, 2018: 125). Fantastik öğeler barındıran The Secret Life of Flowers'ta da benzer bir şekilde olağan/egemen normal dünyadan, sıra dışı/marjinal bir dünyaya geçiş için bir tünel kullanılmıştır.
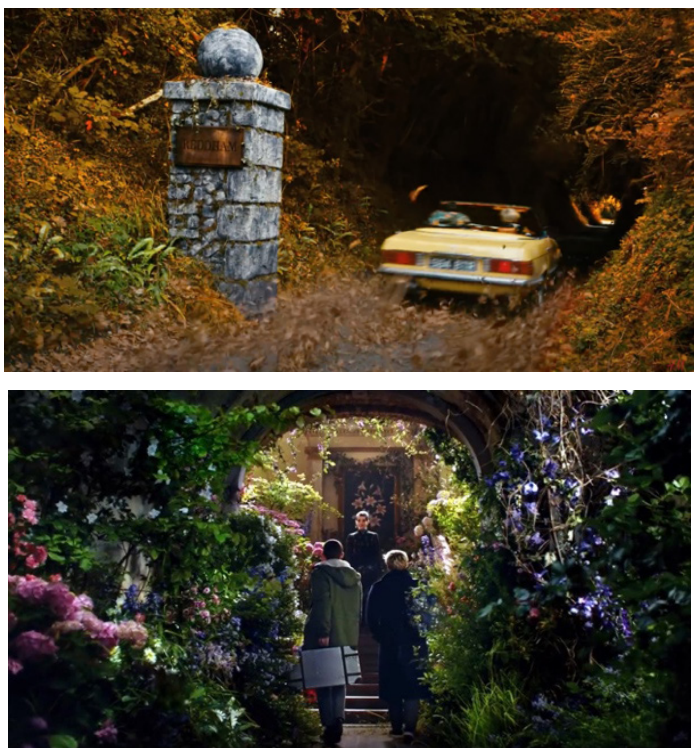

Görsel 1. Eşikler

Adam bu normal dışı dünyayı Tom'un şu sözleriyle birlikte karşılar:

Tom: "Reddham Bahçesi'ne hoş geldin. Burada hep bahar hüküm sürer."

Tom'un bu sözlerinin düzanlamsal ve yananlamsal özelliklerinin olduğu görülmektedir. Düzanlamsal boyutta karakterlerin kıyafetleri çerçevesinde zamanın kış olduğu anlaşılmaktadır. Geçiş yapılan tünelin ikircikli yapısı hem kıştan hem de 
sonbahardan izler taşırken, Reddham Bahçesi'nde ise zaman ilkbahardır. Bu şekilde değerlendirildiğinde düzanlamsal boyut, mevsimsel bir anlamı ortaya çıkarmaktadır.

Ancak Tom'un söylemindeki çağrışımsal düzlem, reklam anlatısının anlam dünyasını açığa çıkarmada çok daha önemlidir. Barthes'ın vurguladığı şekliyle, yananlamsal boyut, izleyiciyi bir tür düşe davet etmektedir. Bu düş ise reklamda hep baharın yaşandığı, egemen normalliklerin ortadan kalktığı, aile gibi otoritelerin geride bırakıldığı, renkli bir yaşam vaat etmektedir. Bu nedenle Adam ve Tom'un yolculuğu, zamanda yolculuğu çağrıştıran, kuralların aşıldığı ve yıkıldığı fantastik bir yolculuğa dönüşür. Çağrışımsal düzlem gerçeğin yıkıldığı ve aşıldığı, fantezinin başladığı bir anı yakalamaktadır.

Adam eşikten geçtikten ve Reddham Bahçesine girdikten sonra dönüşüm kesiti de başlar. The Secret Life of Flowers ta bu kesitle birlikte ikinci bir eşik ortaya çıkar. $\mathrm{Bu}$ eşik ise evin içerisinde bulunmaktadır. Bu eşik tamamen baharı yansıtmakta, rengarenk çiçeklerle kaplı bir geçit gibidir. Adam'ın yüzünde hayret ve hayranlık ifadeleri uyanır. Dönüşüm kesitinde dönüştürücü özne olarak Leydi Demare izleyicinin karşısına çıkmaktadır. Leydi Demare, reklam filminde bir tür öğretici, Adam ise öğretiyi alan kişi olarak değerlendirilebilir. Leydi Demare'nin temel öğretisi ise şu sözlerle belirginleşmektedir:

Leydi Demare: "Normallik dediğin asfalt yol gibidir. Yürümesi kolaydır ama üzerinde çiçek bitmez."

Leydi Demare'nin bu sözleri reklam filminin temel anlam dünyasını yansıtması ve normalliği tanımlaması açısından oldukça önemlidir. Normallik ile asfalt yol arasında kurulan benzetmeye dayalı analojik ilişki ile birlikte, normalliğin kolay olduğu, ancak üretkenlikten ve özgünlükten yoksun olduğu fikri aşılanmaktadır. Çiçek metaforu, reklam filminin hem isminde ve diyaloglarda hem de sıklıkla görsel göstergelerde kullanılmaktadır. Bu açıdan reklam anlatısının en temel öğelerinden biri olarak çiçekler, birçok açıdan anlamın da kurucu öğesi olarak kullanılmaktadır. Çiçekler, içerisinde bulunulan fantastik mekânı, kıyafetleri, bu kıyafetleri taşıyan bireyleri ve sembolik olarak normallik/normaldışılık ikiliğini kodlayan çok katmanlı bir anlam dünyasını sunar. Böylelikle çiçeklerin renkli ve güzel görünümü ile çeşitliliği, normal dışılığın bir özelliği olarak sabitlenir. Leydi Demare'nin çiçeklere ilişkin tanımı, çiçekler ekseninde kurulan bu anlam dünyasını tamamlayıcı niteliktedir:

Leydi Demare: "Açıkçası benim çiçekler arasında favorim yoktur; yabani, özgür ve apansız oldukları sürece."

Leydi Demare'nin bu sözlerinin düzanlamsal olmaktan ziyade yananlamsal, çağrışımsal düzleme ait olduğu ilk bakışta anlaşılmasa da çiçek ile insan arasında benzetmeye dayalı ilişki belirginleştikçe çağrışımsal düzlem açıklığa kavuşmaktadır. Leydi Demare'nin "yabani, özgür ve apansız oldukları takdirde çiçekler arasında ayrım yapmadığını” belirtmesi Reddham Bahçesi'nde ilgi uyandıran ve kabul gören çiçeklerin özelliklerini ima etmesi bakımından önemlidir. Özellikle "yabani” sözcüğü oldukça önemlidir; çünkü yabani kültürel olmayana, doğaya ve doğal olana göndermeleri olan zengin bir kavramdır. Dolayısıyla yabani, kültürel olarak belirlenmiş, sınırları çizilmiş olanın dışına çıkmanın önemli ve değerli olduğunu sembolize eden bir kavram olarak reklamda kodlanmaktadır. Çiçekler ile insanlar arasındaki metaforik ilişki ise Adam'ın 
sözlerinde ortaya çıkmaktadır:

Adam: "Ama Reddham Bahçesi’nde hiçbir şey göründüğü gibi değildi. O gece genç, ünlü ve güzel insanların arasındayken Leydi Demare'nin bahçesinin yeni çiçeği ben mi olacağım diye düşünmeden edemedim."

Adam'ın bahsettiği gibi, dönüşüm kesitinde akşam düzenlenen yemekte, tıpkı Reddham Bahçesi'ne giden geçitte bulunan çiçekler gibi renkli ve güzel insanlar bulunmaktadır. Reklam filminin bu sahnesine kadar atmosferi ve arka planı belirleyen çiçekler, bu sahneden itibaren bireylerin kıyafetlerinde görünen bir desene dönüşür. Adam'ın "bahçenin yeni çiçeği ben mi olacağım" düşüncesiyle birlikte, düzanlamsal ve somut olarak değerlendirilen "çiçek" kavramı soyut ve metaforik bir anlam ağının kurucu öğesi olarak belirginleşir. Redhamm Bahçesi'nin asıl çiçekleri bitkiler değil, insanlardır. Dönüşüm kesiti Adam için bir tür aydınlanma, olay örgüsünü kavrama ve öğretiyi içselleştirme sürecidir.

Reklam filminin bu aşamasına kadar kurucu anlamların serimlendiği görülmektedir. Diğer taraftan yaşananları ve söylemleri anlamlı kılacak gelişmeler bu noktadan sonra başlar ve bütün bu normallik/normal dışılık ikileminin, cinsel kimlikler ve cinsel yönelimlerle ilgili olduğu ortaya çıkar. Leydi Demare'nin Adam'a yönelttiği şu soru reklam anlatısı açısından oldukça önemlidir:

Leydi Demare: "Peki ya siz genç adam? Sizin beğeniniz ne?"

Aniden ve ilk bakışta bağlamsız bir şekilde yöneltilen bu soruyu anlamlı kılan şey, karakterlerin birbirlerine bakışları ve birbirlerini yönlendirici davranışları dikkate alındığında ortaya çıkmaktadır. Davetliler masada otururken Tom'un Adam'a bakışları, Leydi Demare'nin bu soruyu sorarken, Tom'un omuzlarına dokunması gibi detaylar beğenilerin, cinsel yönelimlerle ilgili olduğunu çağrıştırmaktadır. Diğer taraftan bu sorunun ardından reklam filminin bir diğer önemli karakteri Ruby ortaya çıkar ve Adam, Ruby'ye dikkat kesilir.

Adam'ın bu ilgisi hem Leydi Demare'de hem de Tom'da hayrete ve telaşa neden olur. Reklam anlatısının bu sahnesinin son derece karmaşık, zengin çağrışımlara neden olan bir düğümü ortaya çıkardığı ifade edilmelidir. İmalar ve çağrışımlarla yüklü bu sahnede, Adam ile Ruby'nin tanıştırılma biçimi, Tom ile Ruby'nin kardeş olduğunun ansızın öğrenilmesi ve bu durumu Leydi Demare'nin tanımlama şekli oldukça sıra dışı, anormalliğe ilişkin anlamsal çağrışımları beraberinde getirmektedir. Diyalog şu şekilde gelişir:

\author{
Ruby: "Ağabey" \\ Tom: "Kardeşim" \\ Tom: (Adam'ı göstererek) "Adam" \\ Leydi Demare: "Ne kadar baştan çıkarıcı, değil mi?"
}




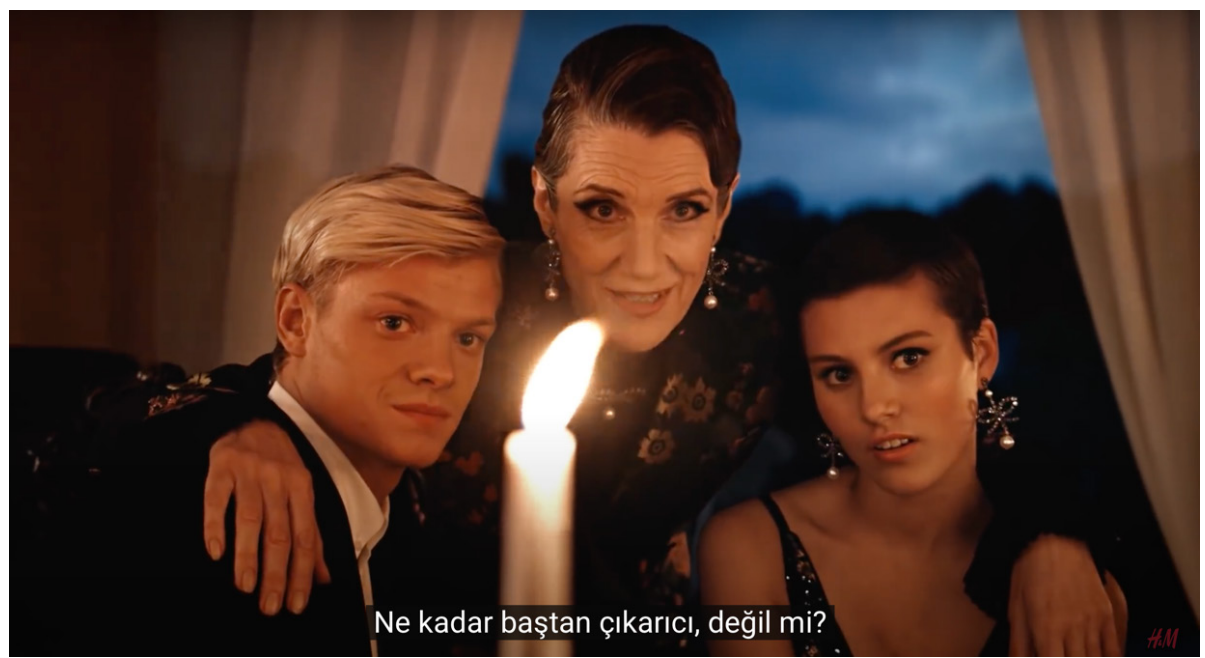

Görsel 2. Leydi Demare, Tom ve Ruby

Leydi Demare'nin bu soruyu Adam'a yöneltirken tam olarak neyi kastettiği, baştan çıkarıcı olan şeyin ne olduğu belirsiz, son derece muğlaktır. Bu noktada bu soruyu anlamlandıracak süreç ve çağrışımlar izleyiciye bırakılmaktadır. Bu sorunun içerimlediği anlamların, çağrışımlara bırakılmasının temel nedenlerinden biri, verilmek ve üretilmek istenen anlamların normallik dışı olması, Zizek'in ifadesiyle paternal Ödipal Yasaya (2018, s. 39) ters düşmesi ile ilgilidir. Bu nedenle reklamda anlamın açıkça verilmesi hem ahlaki hem de yasal engeller nedeniyle mümkün görünmemektedir. Ancak yine de anlam, açıkça olmasa da bir fantezi olarak inşa edilmektedir. Baştan çıkarıcı olan nedir? Tom ile Ruby'nin kardeş olması mıdır? Üç kişilik bir aşk hikayesini düşlemek midir? Beğenilerin akışkan olabilme potansiyeli midir?

Bütün bu sorular cevapsız ve belirsiz kalsa da reklam filminde bu müphemliği ve beraberinde gelen çağrışımları besleyen çeşitli sahneler bulunmaktadır.

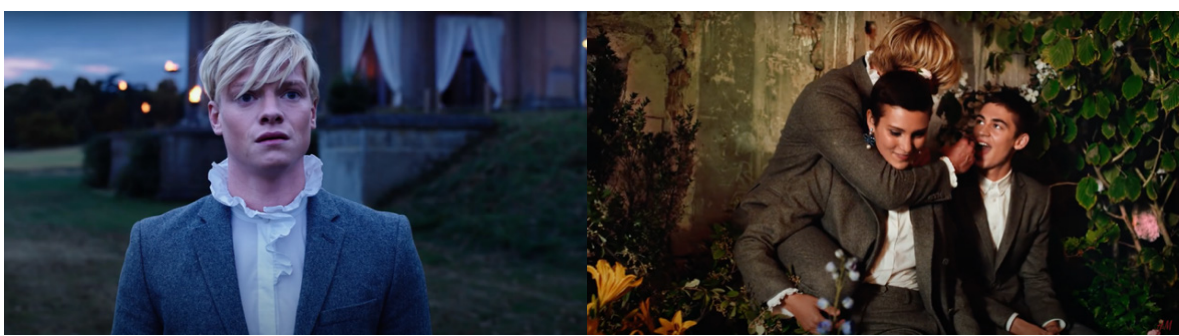

Görsel 3. Tom'un Üzüntüsü

Görsel 4. Üç Kişilik Birliktelikler

Örneğin, Tom'un Adam ve Ruby’yi birlikte gördüğü sahnede duyduğu üzüntünün nedeni tam olarak anlaşılmamaktadır. Adam'ın kardeşi Ruby'ye ilgi duyması, kardeşi Ruby'nin Adam'a ilgi duyması, kendisini bu ilişki ağında dışlanmış hissetmesi gibi intimallerin bu üzüntüye neden olduğu belirtilebilir.

Diğer taraftan bu kesitte Leydi Demare'nin bu soruyu yöneltmesinin ardından, hareketli 
bir müzik eşliğinde davetlilerin fotoğraf çektirdikleri, eğlendikleri ve karakterlerin sık sık kıyafetlerinin değiştiği görünmektedir. Bu görüntü akışında kalabalık içerisinde Tom, Ruby ve Adam sık sık birlikte görünür. En nihayetinde Tom'un üzüntüsü ile birlikte kabullenim/bitiş kesiti başlar.

Reklam filminin son kesitinde Adam, Tom ve Ruby, evin içerisindeki çiçeklerle kaplı bir mekân içerisinde, pijamalarla (ev kıyafetleri/gecelik) görünür. Hem kıyafetler hem de karakterlerin birbirlerine olan yakınlıkları, reklamın anlamsal bütünlüğünü ve inşa edilen nihai anlamı tamamlamaktadır. Reklam filmi, Adam'ın şu sözleri ile son bulur:

Adam: "Keşke hep böyle olsa, hep bahar olsa"

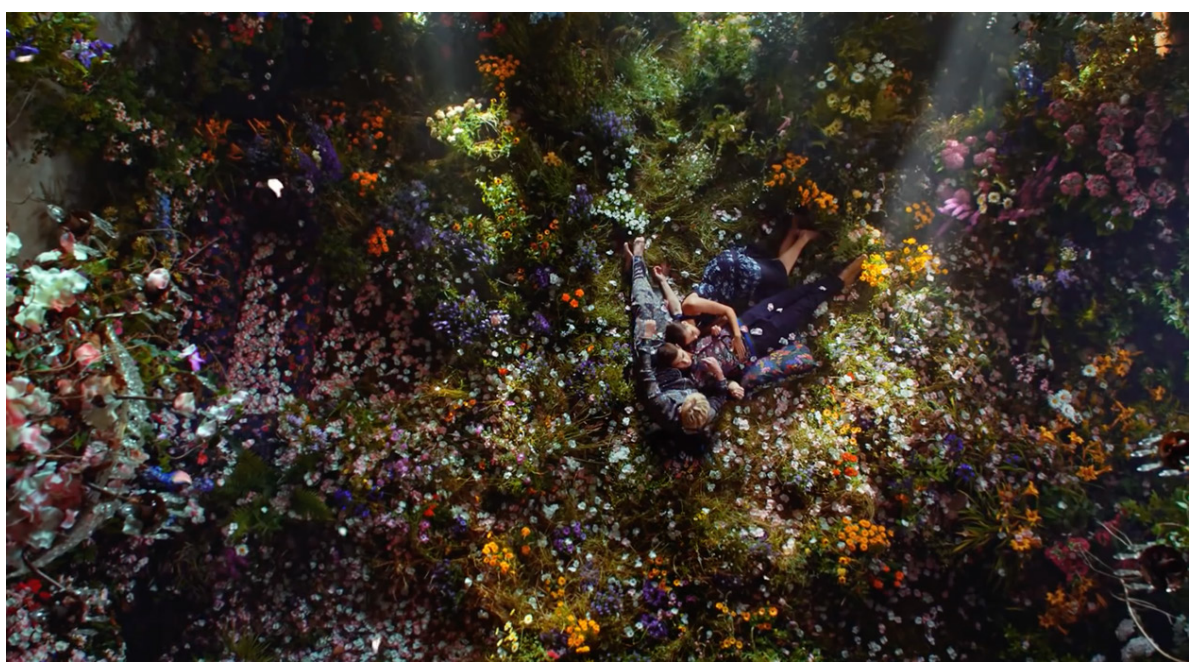

Görsel 5. Doğaya ya da Cennete Dönüş

Adam'ın bahar olarak kastettiği durum son derece muğlak ve farklı okumalara açık olmakla birlikte, şu şekilde betimlenebilir: Adam, Reddham Bahçesi'ne girdikten sonra, dönüşüme uğramış, yeni bir kimliğe kavuşmuştur. Özellikle cinsel kimlik bağlamında Adam'ın akışkan bir cinsel kimliğe büründüğü, yönelimlerinin değişken ve çoklu/melez bir özelliğe kavuştuğu görülür. Bu durum bir tür kültürden özgürleşme ve doğaya/doğal olana dönüş olarak okunabilir. Williamson'un tespit ettiği gibi, reklamların sık sık doğaya dönüş mitini kullandığı, doğanın reklamlarda "kusursuzluk" "tehlike" ve "muzırlık" gibi anlamlara geldiği (2001, s. 126) ve böylelikle reklamlarda tanıtılan ürünlerin doğaya geri götürecek güvenli bir geçit sunduğu (2001: 123) ifade edilmektedir.

Diğer taraftan Williamson (2001, s. 124) bir reklam çözümlemesinde, cinsel beraberlik sonrası imasıyla, bir çiftin bahçeye girişini cennete geri dönüşün çağrışımı olarak okumaktadır. The Secret Life of Flowers'in sonunu bu şekilde okumanın oldukça mümkün olduğu ifade edilebilir. Üstelik ana karakterin adının Adam ${ }^{6}$ olması, bu okumayı daha da olası kılmaktadır. Her iki okuma biçiminde de esas olan, Adam'ın doğaya ya da cennete dönüşü değil, Adam'ın yaşadığı dönüşümün seyri ve niteliğidir. Reklam filminde bu dönüşüm özgürleştirici, mutluluk vaat eden bir pratik olarak sunulmaktadır. 


\subsection{Kıyafetler, Renkler ve Desenler}

The Secret Life of Flowers reklam filminde anlamı inşa etmede kullanılan temel öğelerden biri de kıyafetlerdir. Kıyafetlerdeki renk ve desen seçimleri, reklam filminin dönüşen öznesi Adam'ın kimlik değişiminin seyrini de ortaya koymaktadır. "Psikanalizde giyinme, kişinin cinselliğini yansıtabildiği hal, tavır, konuşma, düş kurma gibi gündelik yaşam pratiklerinden biri sayılır. Psikanalistlere göre, bedenin kılıfı işlevi gören giysiler, insan libidosunun "gizlerini" su yüzüne çıkaran bir dışavurum biçimidir" (Jestratijevic, 2014, s. 211). Bu nedenle kıyafetler, cinsel yönelimlerin temel işaretlerinden ve bunları dışa vuran sosyo-kültürel mekanizmalardan biri olarak değerlendirilmektedir. Kıyafet tercihleri, cinsel yönelimlerin bir sonucu olarak şekillenmektedir.

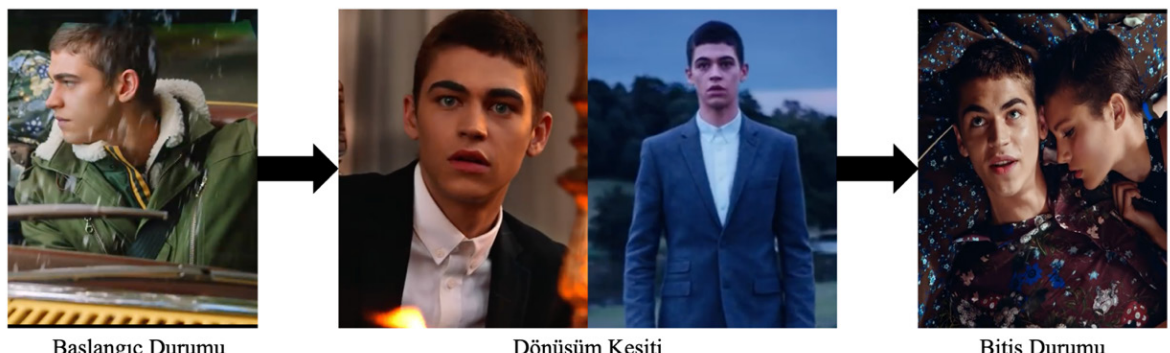

Görsel 6. Kıyafetler Üzerinden Adam'ın Değişimi

The Secret Life of Flowers'ın başlangıç durumunda ve dönüşüm kesitinin ilk kıyafetinde Adam'ın giysileri maskülen nitelikler sergilemektedir. Diğer taraftan dönüşüm kesitinin ikinci kıyafeti ise dönüşümün habercisi olarak değerlendirilebilir, çünkü bu kıyafetle birlikte Adam'ın giderek Tom ve Ruby'ye benzediği görülmekte, hatta kişileri ayırt etmenin giderek zorlaştığı bir benzerlik ortaya çıkmaktadır. Hem kıyafetler hem de karakterlerin saç şekilleri üzerinden cinsel yönelimlerle ilgili müphemliğin inşa edildiği ve akışkan bir forma dönüştürüldüğü reklam filminde, Adam giderek Tom'a ve Ruby'ye benzemeye başlar. Son kesitte ortaya çıkan değişimle birlikte, karakterlerin birbirleriyle benzeşimi çiçekli ve renkli giysiler etrafında ortaya çıkmaktadır. Böylelikle Adam'ın kıyafetlerindeki değişim, cinsel yönelimlerinin değişmesinin sembolik anlatımı olarak değerlendirilebilir.

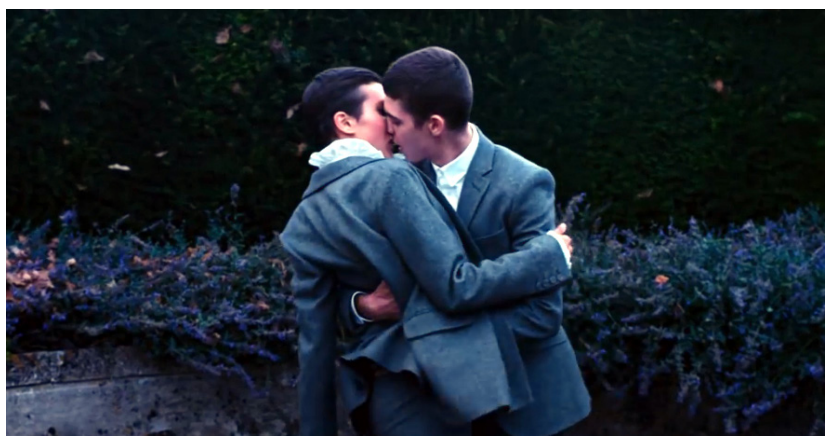

Görsel 7. Benzeşimler ve Müphemlikler 
Reklam filminde müphemlik ve akışkanlık birbirini tamamlayan özellikler olarak kodlanmaktadır. Reklamda ana karakterlerin sürekli giysi değiştirmesi, arka plandaki karakterlerin biyolojik cinsiyetleri ile kimi zaman örtüşen, kimi zaman taban tabana zıt giysileri ve saç şekilleri; biyolojik cinsiyet, toplumsal cinsiyet ve cinsel yönelim/ kimliklerin akışkan, belirsiz ve dönüşüme açık olduğu fikrini vermektedir.

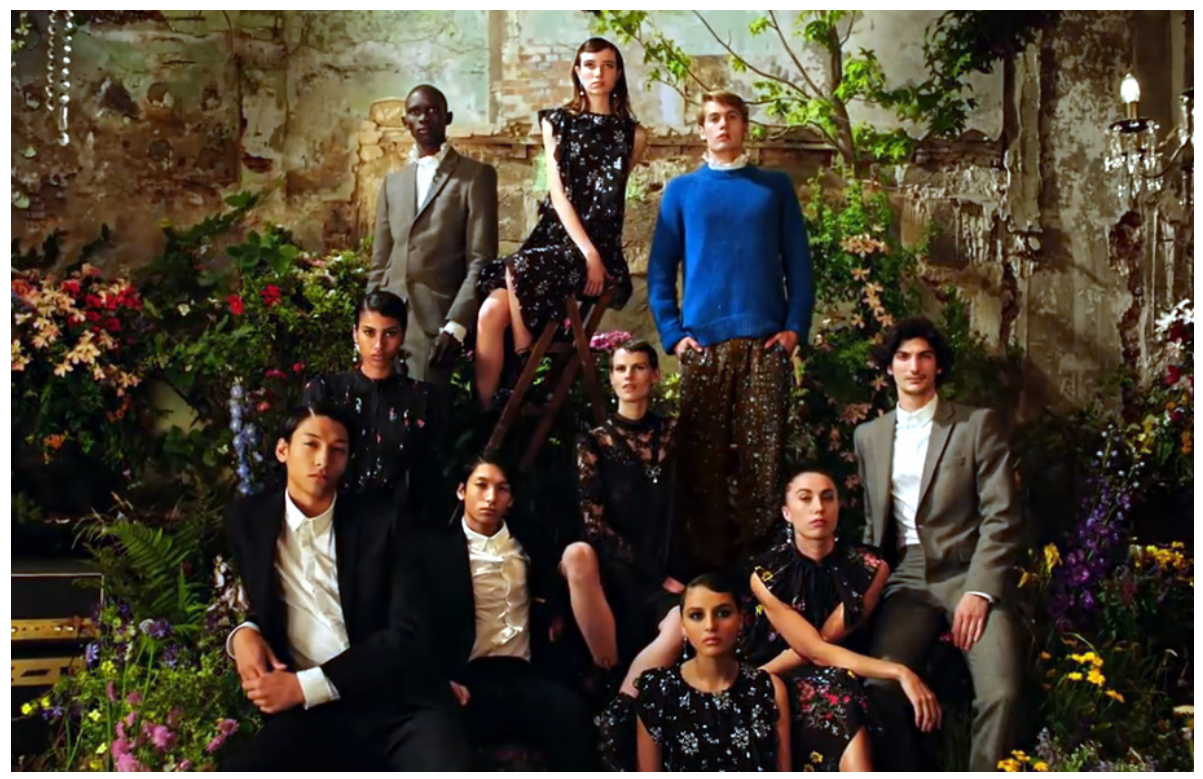

Görsel 8. Akışkan Kosmos

Normallik; kültürel olarak kurulmuş, alışılmış, makul ve meşru kabul edilen bir düzeni ifade eder. Kimlik ve özellikle de cinsel kimlikler söz konusu olduğunda bu kimliği tamamlayan ve ifade eden önemli bir gösterge olarak kıyafetler, cinsel kimlikler ve yönelimlerin sosyal yaşamda öngörülebilir olarak algılanmasında ve kimliğin ifade edilmesinde önemlidir. Bu durum toplumsal kontrol mekanizmaları ile yakından ilgilidir. İnceoğlu ve Kar'ın vurguladığı gibi (2010, s. 137) bedenler toplumsal kontrolün en somut şekilde uygulandığı yerlerden biridir. Kıyafetler ile cinsel kimlikler arasındaki ilişki küçük yaşlardan itibaren kültürel olarak kodlanır. Reklamların çoğunlukla bu kültürel kodları yeniden ürettiği ve bu çerçevede normalliği ve normallik düzenini inşa ettiği görülür. Ancak The Secret Life of Flowers, bu normalliği alt üst eden akışkan bir düzen inşa ederek, belirsizliği ve çeşitliliği vurgulamakta ve "normaldışılığı" fantastik düzlemde normallik biçimine dönüştürmekte, normaldışıı̆̆ düşlenen bir olgu haline getirmektedir. Sonuç olarak, fantastik anlatıya başvuran The Secret Life of Flowers'ın ortaya koyduğu akışkan kosmos, Tolkien'in ifadesiyle cezbedici tuhaflık (1999, s. 69) işlevi görmektedir. Bu tuhaflık arzunun uyandırılması ile ilgilidir.

\subsection{Temel Karșitlıklar}

Daha önce de ifade edildiği gibi, göstergebilimsel yaklaşıma göre anlamlar üretilen 
karşıtlıklara göre inşa edilmektedir. Bu bağlamda The Secret Life of Flowers reklam filminde anlamın kurulumunda kullanılan temel karşıtıklar Tablo 1.'de gösterilmektedir.

Tablo 1. Reklam Filminde Temel Karşıtlıklar

\begin{tabular}{|c|c|}
\hline Maskülen & Feminen \\
\hline Akışkan & Katı \\
\hline Normal & Normal dışı \\
\hline Gerçek & Düşsel/Fantezi \\
\hline
\end{tabular}

Cinsiyetin konu edinildiği anlatılarda kullanılan en temel karşıtlıklardan biri kadın/ erkek karşıtığıdır. Bu karşıtlık sayesinde genellikle cinsiyet rollerine ilişkin anlamların üretildiği görülmektedir. Ancak The Secret Life of Flowers'ın gerek kıyafet seçimleri gerekse cinsel yönelimler çerçevesinde kadın/erkek karşıtlığına yer vermediği görülmektedir. Bunun yerine bir hal, tavır ve tarz gibi içerimleri bulunan maskülen/ feminen karşıtığının, anlamın kurulmasında kullanılan temel karşıtlıklardan biri olduğu görülür. Maskülen/feminen karşıtığının da egemen bir kuruluma bağlı kalmadığını, yani maskülenliği erkekliğe, feminenliği kadınlığa bağlayan bir karşıtık ilişkisinin olmadığı ifade edilmelidir. Çünkü örneğin, biyolojik olarak erkek olan Tom feminenliği, diğer taraftan biyolojik olarak kadın olan Ruby ise maskülenliği temsil eder. Dolayısıyla bu karşıtlık, katı bir belirlenim olarak değil, akışkan bir belirlenim olarak reklam filminde kullanılmaktadır.

Bir diğer önemli karşıtık ilişkisi akışkanlık/katılık ekseninde şekillenmektedir. Reklam filminin en temel ve nihai olarak ortaya koyduğu ve inşa ettiği anlamlandırma sürecinin de bu karşıtık ilişkisi üzerine inşa edildiği görülmektedir. Adam'ın katı, sabit ve kuralları belirli bir gerçeklikten; akışkan, değişken ve şekil değiştirebilir bir fantastik evrene geçişi, gerçek dünya ile düşsel dünya arasındaki zıtlığı vurgulamaktadır. Bu noktada da gerçek/düşsel karşıtığının devreye girdiği görülmektedir.

Gerek hikâye örgüsü ve görsel göstergeler gerekse söylem düzeyinde belirginleşen ve anlatı içerisinde sürekli olarak iş gören temel zıtlıklardan biri de normallik/normaldışılık karşıtığıdır. Bu karşıtıı ilişkisi içerisinde reklam filminin normallik ve normal dışılığa ilişkin tanımlarının, normalliği sorgulamaya davet eden bir işlevi bulunmaktadır.

\section{Sonuç}

Fantastik anlatı içerisinde çeşitli eşikler aşarak ilerleyen kahramanlar, yolculuğa çıkmasına neden olan sorunu aştıktan ve kendisi olmayı, kendini keşfetmeyi başardıktan sonra eve geri döner. Fantastik anlatının izleği, doğrusal değil, döngüseldir. Kahraman eve dönmediği sürece hikâye tamamlanmaz. İlk bakışta Adam'ın başlangıç durumuna geri dönmediği iddia edilebilirse de Adam'ın bitiş durumunda Reddham Bahçesinde ikamet etmeye başlaması ve anlatının doğaya/cennete dönüş mitini tekrarlaması; reklam filminin bir eve, kendine, öze dönüş hikayesi olduğunu ima eder. 
Rank (2018, s. 81) mitlerin sürekli anne babadan kurtulma çabası gösterdiğini, aynı çabanın kişisel bağımsızlığını kurmaya çalışırken çocuğun fantezilerinde de ortaya çıktığını belirtir. The Secret Life of Flowers başlangıcından itibaren aileden kopuş ve özgürleşme hikayesi olarak anlam kazanmaktadır. Özgürleşmenin konusu ise cinsel kimlikler ve yönelimler çerçevesinde şekillenir. Reklam filminin alt metninde, bu özgürleşme ve kendini bulma konusunun yer aldığı ifade edilmelidir.

Diğer taraftan modern anlatıların arketiplere dayandığını vurgulayan Eliade, mitsel anlatılarda ikamet etme ya da yaşamsal alan olarak kullanılma amacı taşıyan her toprağın, her şeyden önce "kaos”tan "kosmos"a dönüştürüldüğünü, bu şekilde de bir gerçekliğe kavuşturulduğunu (2017, s. 24) söyler. The Secret Life of Flowers'ın bu mitsel arketip üzerine inşa edildiği oldukça açıktır. Çünkü başlangıçta kaotik olan her şey, reklam filminin sonunda Adam için anlaşılabilir, kabul edilebilir bir kosmosa dönüşür. Bu kosmos ayrıca Adam'ın özgürleştiği bir düzeni içerir. The Secret Life of Flowers bir kahramanın yolculuğu olarak okunduğunda; reklam filminde izleyiciye/ tüketiciye, cinsel yönelimler ve arzular zemininde, markanın özgürleştirici potansiyeli ve tüketicinin markayla kendini olduğu/hayalini kurduğu kişiye dönüştürebileceği mesajı verilmektedir. Çoğu reklamda cinsellik, arzu ve marka/ürün arasında bu tür bir ilişkinin kurulduğu görülmekle birlikte The Secret Life of Flowers'ın farklı, sabitliği olmayan, akışkan bir deneyime çağrıda bulunduğu anlaşılmaktadır.

\section{Extended Abstract}

Advertisements are not only intended to promote or sell a product today; In addition, semiotic world produced in the advertisements and attached to the brand / product shows that the advertisements offer the consumer a lifestyle, an identity or various patterns of belonging. Just as ads need a product to promote, they also need an idea and a feeling that will appeal to the consumer with the product. For this reason, advertising activities are not only for the individual's material needs; It is seen that it strives and claims to meet many social and psychological needs such as social status, prestige, class belonging and identity expression. Today, one of the spheres where advertisements are mostly directed is identity. Advertisements emphasize that a certain identity can be acquired by purchasing the product. For this reason, a close relationship is established between product and identity in advertisements.

Marshall states that identity is used in a broad and flexible way by referring to one's own sense of self, feelings and opinions about oneself (1999, s. 407). The debates and researches about identity in social sciences have sociological tradition at one end and psychodynamic tradition at the other. It is seen that sociology deals with identity especially within the framework of social / cultural determinations. Biological determination is also taken into account when it comes to sexual identity. However, in the psychodynamic tradition, the idea that anatomy does not determine sexual position (Evans, 2019, s. 72) is accepted as one of the basic axioms of psychoanalytic theory.

In the subject of sexual identities, it is emphasized that a fluid, constantly renewed field of identity acquisition / experience has opened up in different fields of experience. 
According to Bauman, who stated that identity construction has taken the form of an unstoppable experiment (2017b, s. 103), the password of our age is resiliency: "All forms must be soft, all conditions are temporary, all shapes must be suitable for forming. Reshaping in an obsessive and dependent way is both a duty and a necessity" (2018a, s. 124). In this way, sexual identities are diversified by embracing a wide world of meanings in a field of experience, taking on a fluid quality. Liquid sexuality is used as an advertising attraction in some advertisements today.

One of the most used narrative elements of advertising is sexuality. The fact that sexuality is used in advertisements, sometimes directly and mostly in an associative plane, is undoubtedly a result of the principle of "sexuality always sells". Sexual appeal as a type of attraction aims to attract the attention of the viewer to the advertisement message, eventually to transform the brand / product into an object of desire, and to instill a perception that the sexual attraction will be increased by owning the product. Although there are exceptional cases, it can be stated that sexual attraction is mostly used within the heterosexual semantic world and discourse order in advertisements.

The idea of satisfying the desire given in advertisements is an illusion and advertisements are not about the fulfillment of desire, but about the awakening and stimulation of desire. As Bauman pointed out, "the consumption order in its current form is not based on the regulation of desire, but on the release of hopeful fantasies, as Harvie Ferguson points out" (Bauman, 2017a, s. 120).

Within the scope of this study, it is seen that The Secret Life of Flowers commercial film, which is the subject of the analysis, resorts to sexual attraction, but has a fluid and ambiguous discourse of sexuality that transcends borders, especially at the associative level. On the other hand, it can be stated that The Secret Life of Flowers commercial is enriched with fantastic elements and addresses the audience within the framework of an imaginary universe. In this respect, it differs from the common advertising understanding.

The semiotic analysis method was used in the analysis of the commercial film. General description of the advertisement has been made; the narrative structure consisting of person, time, space and discourse, clothes and basic contrasts are analyzed. The contrast between "normality" and "abnormality" in the narrative structure of the commercial film is drawn with various dialogues and visual indicators. While normality and abnormality are presented as antagonistic and do not contain each other, it is seen that various thresholds are used in advertising to split the two from each. Thus, The Secret Life of Flowers creates a semiotic world that questions "normality" and reproduces the myth of return to nature / heaven. Some contrasts were used in the construction of the basic meaning in the commercial. These contrasts emerge as; it emerges as masculine / feminine, fluid / solid, normal / abnormal and real / fantasy. The traces of the change experienced by the main character Adam are also evident in the costumes of Adam. Adam, who is seen wearing "normal" costumes at the beginning of the narrative, has attained a colorful appearance like the people around him at the end of the narrative. This situation implies that identity and change are fixed on clothes.

When The Secret Life of Flowers is read as a hero's journey; In the commercial, the 
message is given to the audience / consumer on the basis of sexual orientations and desires, the liberating potential of the brand and that the consumer can transform himself / herself into the person he / she dreams of with the brand. Although it is seen that such a relationship is established between sexuality, desire and brand / product in most advertisements, it is understood that The Secret Life of Flowers calls for a different, resilient and fluid experience.

\section{Kaynakça}

Barthes, R. (2003). Çağdaş Söylenler. (T. Yücel, Çev.), İstanbul: Metis Yayınları.

Barthes, R. (2009). Göstergebilimsel Serüven. (M. Rifat ve S. Rifat, Çev.), İstanbul: YKY.

Baudrillard, J. (2004). Tüketim Toplumu. (H. Deliceçaylı ve F. Keskin, Çev.), İstanbul: Ayrıntı Yayınları.

Bauman, Z. (2017a). Akışkan Modernite. (S. O. Çavuş, Çev.), İstanbul: Can Yayınları.

Bauman, Z. (2017b). Kimlik. (M. Hazır, Çev.), Ankara: Heretik Yayınları.

Bauman, Z. (2018a). Akışkan Hayat. (A. E. Pilgir, Çev.), İstanbul: Ayrıntı Yayınları.

Bauman, Z. (2018b). Kuşatılmış Toplum. (A. E. Pilgir, Çev.), İstanbul: Ayrıntı Yayınları.

Berger, J. (2010). Görme Biçimleri. (Y. Salman, Çev.), İstanbul: Metis Yayınları.

Budak, S. (2005). Psikoloji Sözlüğü. Ankara: Bilim ve Sanat Yayınları.

Butler, J. (2012). Cinsiyet Belası. (B. Ertür, Çev.), İstanbul: Metis Yayınları.

Clero, J-P. (2011). Lacan Sözlüğü. (Ö. Soysal, Çev.), İstanbul: Say Yayınları.

Çabuklu, Y. (2006). Bedenin Farklı Halleri. İstanbul: Kanat Yayınları.

Dökmen, Z. Y. (2012). Toplumsal Cinsiyet. İstanbul: Remzi Kitapevi.

Elden, M. ve Bakır, U. (2010). Reklam Çekicilikleri. İstanbul: İletişim Yayınları.

Elden, M., Ulukök, Ö. ve Yeygel, S. (2014). Şimdi Reklamlar. İstanbul: Iletişim Yayınları.

Eliade, M. (2017). Ebedi Dönüş Miti. (A. Meral, Çev.), İstanbul: Dergâh Yayınları.

Evans, D. (2019). Lacancı Psikanalize Giriş Sözlüğü. (U. Y. Kaya ve T. Sivrikaya, Çev.), İstanbul: Islık Yayınları.

Fiske, J. (2003). Illetişim Çalışmalarına Giriş. (S. İrvan, Çev.), Ankara: Bilim ve Sanat Yayınları.

Gleason, P. (2014). Kimliği Tanımlamak: Semantik Bir Tarih. F. Mollaer (Der.). Kimlik Politikaları: Tanınma, Özdeşlik ve Farkııık (s. 21-52) içinde. Ankara: Doğu Batı Yayınları.

Göker, G. ve Göker, N. (2018). Düşsel Bir Eşikten Geçeceksin: A Magical Holiday Reklam Filminde Fantazya. Erciyes Iletişim Dergisi, 5/4, 123-142.

Güler, M. (2019). Yönlendirilen Arzu. Ankara: Ütopya Yayınları. 
İnceoğlu, Y. ve Kar, A. (2010). Kadın ve Bedeni. İstanbul: Ayrıntı Yayınları.

Jestratijevic, I. (2014). Moda ve Fetişizm Yıkıcı Anlamlar. T. Erdem, S. Ergül (Der.). Fetiş íkame (s. 206-221) içinde. İstanbul: Sel Yayınları.

Küçükerdoğan, R. (2009). Reklam Nasıl Çözümlenir? İstanbul: Beta Yayınları.

Lacan, J. (2014). Psikanalizin Dört Temel Kavramı. (N. Erdem, Çev.), İstanbul: Metis Yayınları.

Lefebvre, H. (2007). Modern Dünyada Gündelik Hayat. (I. Gürbüz, Çev.), İstanbul: Metis Yayınları.

Marshall, G. (1999). Sosyoloji Sözlügü. (O. Akınhay ve D. Kömürcü, Çev.), Ankara: Bilim ve Sanat Yayınları.

McGowan, T. (2018). Sahip Olmadığımız Şeyin Keyfini Sürmek. (K. Güleç, Çev.), Ankara: İmge Yayınları.

Mercer, K. (1998). Cangıla Hoşgeldiniz: Postmodern Politikada Kimlik ve Çeşitlilik. (í. Sağlamer, Çev.). Kimlik: Topluluk/Kültür/Farklıık (s. 49-84) içinde. İstanbul: Sarmal Yayınları.

Mollaer, F. (2019). Kimlik, Tanınma Mücadelesi ve Şarkiyatçılık. İstanbul: Metis Yayınları.

Parekh, B. (2014). Kimliğin Mantığı. F. Mollaer (Der.). Kimlik Politikaları: Tanınma, Özdeşlik ve Farkııık (s. 53-76) içinde. Ankara: Doğu Batı Yayınları.

Plummer, K. (2008) Kimlik. W. Outhwaite (Ed.), Modern Toplumsal Düşünce Sözlügü (s. 418-420) içinde. İstanbul: İletişim Yayınları.

Rank, O. (2018). Kahramanın Doğuş Miti. (G. Yavaş, Çev.), İstanbul: Pinhan Yayınları.

Reichert, T. (2004). Reklamcılığın Erotik Tarihi. (L. Yazmacıyan ve V. Bora, Çev.), İstanbul: Güncel Yayıncılık.

Rifat, M. (2007). Homo Semioticus ve Genel Göstergebilim Sorunları. İstanbul: YKY.

Rifat, M. (2009). Göstergebilimin ABC'si. İstanbul: SAY Yayınları.

Rifat, M. (2013). Açıklamalı Göstergebilim Sözlüğü. İstanbul: İş Bankası Kültür Yayınları.

Rutherford, J. (1998). Yuva Denilen Yer: Kimlik ve Farklılığın Kültürel Politikaları. (ì. Sağlamer, Çev.). Kimlik: Topluluk/Kültür/Farklılık (s. 7-29) içinde. İstanbul: Sarmal Yayınları.

Todorov, T. (2012). Fantastik. (N. Öztokat, Çev.), İstanbul: Metis Yayınları.

Tolkien, J. R. R. (1999). Peri Masalları Üzerine. (S. Erincin, Çev.), İstanbul: Altıkırkbeş Yayınları.

Williamson, J. (2001). Reklamların Dili. (A. Fethi, Çev.), Ankara: Ütopya Yayınları.

Woodward, I. (2016). Maddi Kültürü Anlamak. (F. B. Aydar, Çev.), İstanbul: İş Bankası Kültür Yayınları.

Zizek, S. (2018). Cinsel Olan Politik midir? (B. Turan, Çev.), İstanbul: Encore Yayınları. 